Boise State University

ScholarWorks

Communication Faculty Publications and

Presentations

Department of Communication

4-29-2014

\title{
A Historical Comparison of the Social Origins of Broadcasting Policy, 1896-1920
}

Seth Ashley

Boise State University 


\title{
A Historical Comparison of the Social Origins of Broadcasting Policy, 1896-1920
}

\author{
Seth Ashley \\ Boise State University
}

\begin{abstract}
Using the United States and Great Britain as a comparative case study, this article employs an historical institutionalist framework to consider the broad array of social, cultural, political and economic contexts that led to divergent outcomes in the early development of broadcast policy. This comparative historical analysis reveals the causal chains formed before the 1920s despite a period of post-war contingency. As a policy option, government control was removed in the U.S. but stayed in place in Britain after the war. This comparative approach can help to explain policy outcomes and inform modern policy debates.
\end{abstract}

The possibility of broadcasting - though not the idea of it—was born when an Italian named Marconi used his "black box" to transmit telegraph signals wirelessly in 1895 (Barnouw, 1966; Rosen, 1980; Douglas, 1987). It would be more than two decades until the perceived problems of early wireless communication-messages went from a sender to many receivers rather than just to the intended recipient—-would be reconceived as an amazing new mass medium. In the intervening years, as broadcasting began to be conceptualized, a legacy of policy was being born.

The legacy of early broadcasting policy continues to have lasting effects in media systems around the world, especially today as nations grapple with the political and economic structure of the Internet and new digital technologies. But where did these policies come from and how can they be improved? The origins of broadcasting and the related communication policy outcomes in various democracies of the world reflect dramatically different understandings of the relationship between state and society, between markets and individuals. At the heart of these - and any - disputes over the role of the state is the tension between private and public, a push and pull between the forces of political and economic power on the one hand and the impulse toward democracy and equality on the other. An examination of these broad social forces and their application in broadcasting invites a broad historical perspective, with attention to critical junctures, path dependence and temporal sequencing (Thelen, 1999; Pierson \& Skocpol, 2002; Pierson, 2004). How, when and why did different approaches to structuring media systems arise, and how, when and why were they ultimately adopted or rejected?

Using the United States and Great Britain as a comparative case study, this article employs an institutional framework to consider a broad array of social, cultural, political and economic contexts that guide the development of patterns of human organization and behavior. The U.S. and Great Britain exemplify the extremes of divergent broadcast policy outcomes. In the 1930s, the U.S. broadcast media system emerged fully formed as a commercial, for-profit industry; the British Broadcasting Corporation was a publicly funded state monopoly. How can we explain these divergent outcomes, considering that they came from relatively similar western, industrialized democracies?

The historical approach, with attention to critical junctures, is necessary to look back and see where significant patterns emerged and whether they were adopted or avoided. Within the historical institutionalist context, an emphasis on path dependence highlights the temporal element of processes that often exhibit considerable stability until times of change, when decisions are made, paths are selected and alternatives are pushed aside. In politics and policymaking, a path, once taken, can be difficult to alter. According to Thelen, "Politics involves some elements of chance (agency, choice), but once a path is taken, then it can become 'locked in' as all the relevant actors adjust their strategies to accommodate the prevailing pattern" (Thelen, 1999, p. 385). These prevailing patterns lead to periods of stability and equilibrium but are also said to be punctuated by critical junctures and policy windows that affect future choice options (Arthur, 1989; Baumgartner \& Jones, 2009; Pierson, 2000, 2004). Path dependence helps explain how this process occurs. "History matters" is the bumper-sticker explanation of path dependence, which is also commonly defined by Sewell's conceptualization that "what happened at the earlier point in time will 
affect the possible outcomes of a sequence of events occurring at a later point of time” (Sewell, 1996, p. 262-263). While human agency can be constrained by these path dependent processes, the nature of critical junctures makes it clear that outcomes, rather than being predetermined, remain contingent on human actions.

The advent of broadcasting is an obvious critical juncture in the history of communication due to the rapid establishment of policies required to structure and govern the emerging technologies. With an eye toward today's media policymaking process, this study seeks to understand the paths already in place at the advent of broadcasting and the paths that emerged as broadcasting evolved that helped dictate the options available — and unavailable- to communications policymakers.

\section{International Origins}

Although the idea of broadcasting had yet to be conceived, even in the first decade of the twentieth century, the air was already being thought of as property to be owned or controlled (Douglas, 1987; Barnouw, 1966). Governments in Europe and the U.S. were quick to see the international dilemma in managing the ether. This early realization led to a series of international conferences and conventions to seek consensus on frequency management and allocation. The First International Radio Telegraphic Conference was sponsored by Germany and held in Berlin in 1903. Seven nations attended and addressed disputes about communication between stations owned by different companies and minimizing interference. The delegates were asked to review the issues and reconvene in another international conference, which happened in 1906, again in Berlin. This convention worked out technical details and transmission rates, questions originally raised in the 1903 meeting (Howeth, 1963).

The 1906 convention was attended by representatives from 27 countries, ranging from Russia to Denmark to Turkey to Brazil. The provisions agreed upon were to be applied to "all radio stations open to public service between the coast and vessels at sea," and the countries were to "make the observance of these provisions obligatory upon private enterprises authorized" to establish and operate stations of all kinds (United States Navy Department, 1912, p. 3). One of the main sticking points was between the British and American delegations, as the British had already entered into contracts with Marconi's company that prohibited the exchange of signals with equipment made by other manufacturers (Howeth, 1963, p. 120). Article 3 of the proposed treaty read simply: "The coastal stations and the stations on shipboard shall be bound to exchange radiograms without distinction of the radio system adopted by such stations” (United States Navy Department, 1912). The American delegation called the acceptance of Article 3 "indispensable" and said it should "serve as the basis of an international agreement." They addressed objections by noting that the U.S. Navy had demonstrated that "the different systems of radio telegraphy can be effectively used simultaneously one with the other." The Navy "is actually using at present eight different systems," they noted (Tower, 1906). A compromise was reached that would allow the British time to construct new transmitting stations that would not be bound by the Marconi contracts.

Despite the American victory regarding the inclusion of Article 3 and President Roosevelt's and the Navy's recommendation that the proposed treaty be ratified by the Senate, hearings by the Committee on Foreign Relations in 1908 led to a different outcome (International Wireless Telegraph and Hearings, 1908). After hearing from representatives of industry and government, the committee recommended a "wait-and-see" approach. In a memorandum to the committee, the American branch of the Marconi Company objected to the treaty because "it is taking the property of the Marconi Company and subjecting it to the use and service of others against the will of the owners, and to their injury" and "because the Convention, if adopted by the United States, will impair the value of the patents issued to Marconi and thus violate the national faith" (International Wireless Telegraph and Hearings, 1908, p. 66). The Marconi company felt that its "refusal to agree" to the terms of convention "is unjustly represented as contrary to all precedent and against the public interest" (p. 68). The company also complained that the convention "commits this Government to the policy of Government operation of wireless telegraphy for commercial purposes" (p. 64). The Marconi Company thus suggested that the public interest was aligned with business interests and invoked in its defense the "national faith" in the government's ability to uphold patents. To the Marconi Company, adopting the convention's recommendations would amount to a government takeover of wireless. 
Among the witnesses before the committee was John W. Griggs, president of the American branch of the Marconi Company and former U.S. attorney general. Griggs told the committee that the Marconi Company would not be opposed to regulations "where humanity or public necessity require it," as in the case of distress signals, but suggested that the terms of the convention amounted to a European-style government takeover of industry (International Wireless Telegraph and Hearings, 1908, p. 53). In his parting words, Griggs told the committee that

the control here provided for is the kind of control that they are accustomed to in Europe where the governments themselves operate many of the agencies of public service....There it is considered an ordinary thing to take a public invention and use it and carry it on by the government. Here [in the U.S.] the principle adopted is to allow private ownership subject only to such public regulation as is necessary in the interest of the public (p. 61).

On the other hand, John I. Waterbury, a representative from the Department of Commerce and Labor who had been part of the U.S. delegation to the Berlin convention and favored its implementation in U.S. law, wrote that a failure to regulate the growing technology represented "serious curtailment of the vast benefits to humanity which the discovery had promised" and would be "detrimental in high degree to public welfare in the broadest application of the term" (International Wireless Telegraph and Hearings, 1908, p. 124). Waterbury noted that Marconi stations had engaged in the practice of "drumming," or "filling the atmosphere with a series of powerful electrical waves thrown out at short intervals" to intentionally produce interference (p. 126). Similarly, Lieutenant-Commander of the Navy Cleland Davis told the committee that the Navy was "often greatly annoyed" by the problem of malicious and unintentional interference. "The public interests demand that this be regulated," he said (p. 100). In the end, the wait-and-see approach suggested by the committee and adopted by the Senate was a victory for members of an emerging industry, who were not yet ready to be regulated.

What is noteworthy here is that Article 3 aimed to promote public welfare by ensuring that distress calls could be uniformly sent and received, a goal that was ultimately opposed by both the U.S. and the British on the grounds that it interfered with arrangements with industry even if it was actually a modest attempt to save lives. A retired naval officer wrote in 1963 that the proposal was an essentially "humanitarian" measure, referencing a 1906 report from a naval officer to the Chief of the Bureau of Equipment that was part of the testimony before the Senate Committee on Foreign Relations (Howeth, 1963, p. 122). The report cited, for example, the "outrageous instance of a Marconi station interfering to prevent communication between a U.S. Government vessel that had suffered loss in a storm and desired to send notice to the authorities, and an American Merchant steamer; on the ground that the wireless instruments on the government vessel was not of the Marconi system" (Howeth, 1963, p. 122). What seems like a fairly reasonable policy goal—ensuring uniform ship-to-ship and ship-to-shore transmissions in order to promote emergency communication, or what was called "compulsory intercommunication"-was essentially thwarted by business interests and legal frameworks in both the U.S. and Britain.

Even though no actions were taken at this point, these early international agreements and the resistance they faced already made two significant contributions to later conceptualizations of broadcasting. The first was to introduce the notion of "public service," which even if it was limited to communication to and among ships at sea, still presupposed that wireless technology should exist for reasons beyond mere private gain and should purport to provide some type of service to the public good. The second contribution was to suggest that even privately owned or operated wireless stations should be regulated by the state and forced to conform to international agreements. The future debates over the role of the state in regulating broadcasting continued to take shape as future policy "scripts" continued to be written.

\section{America: Questions of Control}

In the U.S., the first major recommendation on how to structure and regulate the new wireless technology came in 1904 from the Inter-Departmental Board on Wireless Telegraphy (Inter-Departmental Board, 1905). The board consisted of three Navy officials, one Army official, and one representative of the Department of Agriculture. The "Roosevelt Report," which they presented to the President, contained three significant conclusions that would begin to chart a course toward the government's role in broadcasting in the U.S. First, the Navy wanted to maintain strong control over "a complete coastwise system of wireless telegraphy" for the "efficient and economical management of the fleets of the United States in time of peace and their efficient maneuvering in time of war." Second, the board felt that wireless stations should fall under the jurisdiction of just one government department. Third, and most 
This is an author-produced, peer-reviewed version of this article. The final, definitive version of this document can be found online at Journal of Radio \& Audio Media, published by Taylor and Francis. Copyright restrictions may apply. doi: 10.1080/19376529.2014.891210

important, the board left room for the possibility of commercial stations and recommended that they be controlled by the Department of Commerce and Labor. The board wrote that "the Government must take the necessary steps to regulate establishment of commercial wireless-telegraph stations among the States and between nations” (InterDepartmental Board, 1905, p. 549-550).

To this end, the board requested legislation to allow Navy control of wireless stations and did not hesitate to invoke the public interest as a central rationale:

The Board believes it to be in the interest not only of governmental but public economy and efficiency to permit the naval stations to handle the public service, for in the present state of the art but one station is desirable for the public interests in such places. As the needs of the Navy are paramount on account of the problem of national defense, private stations should not be allowed to locate to the disadvantage of the former. Moreover, there is at present no public need for multiplication of stations at these points (p. 550).

The "interest," even in this early report, is clearly one of efficiency, and the exclusivity of control is justified by an appeal to the problem of national defense. The report does go on to allow for the future possibility of licensed commercial operations:

It is admitted, however, that there may be special cases where private stations can serve a useful purpose, and the Board believes that the Department of Commerce and Labor should have the duty of issuing licenses in such cases under such regulations as will prevent interference with stations necessary to the national defense. All private stations in the interior of the country should also be under supervision of the Department of Commerce and Labor (p. 550).

The proposed method of licensing private stations under the Department of Commerce would have a lasting effect, to the dismay of the Post Office, which also sought control of wireless. The report went on to recommend "full Government supervision" in order to regulate private stations "for their mutual and public welfare, as well as from considerations of national defense.” The board believed that, in addition to solving technical problems, government control of private stations would be important because "it seems desirable that there should be some wholesome supervision of them to prevent the exploitation of speculative schemes based on a public misconception of the art." The board also felt that the Navy was poised to facilitate enterprise and innovation, but that supervision by the Commerce department was essential "to prevent the control of wireless telegraphy by monopolies or trusts."

The U.S. government was slow to act on this front, allowing a foreign interest to gain what would become an unwelcome foothold. "By 1912 this shortsightedness, combined with the unscrupulous methods of radio stock promoters, resulted in the survival of only one important American radio operating company, the Marconi Wireless Telegraph Co. of America, a subsidiary of British Marconi” (Howeth, 1963, p. 313). It was clear that the Navy was no fan of Marconi and his early monopoly on wireless. In a 1904 letter to the Department of Commerce, the InterDepartmental Board that had produced the Roosevelt Report made their feelings known:

This company has played a bold game, calculated to "hold up" the Government in this matter and in its negotiations with the Navy Department, and the board is of the opinion that its action in regard to the light-ship and its refusal to receive messages at any of its stations from other systems are strong arguments in favor of Government supervision of private stations (Inter-Departmental Board, 1905, Appendix B).

But regulation was slow to come. European governments endorsed the international treaties in 1903 and 1906, and made laws to reflect them. Even though the U.S. signed the agreement at the 1906 Berlin convention, no formal laws were made as wireless companies and amateurs lobbied against regulation from 1904 to 1910. Regulation of wireless was also a low legislative priority in Congress, which was dealing with more salient issues related to child labor and the meatpacking industry. Plus the technology was so poorly understood that no one was sure how to regulate it anyway (Douglas, 1987). Congress finally took action after a 1909 shipping accident prompted legislation (Slotten, 2000). This came in the form of the Wireless Ship Act of 1910, which required that ships be able to 
This is an author-produced, peer-reviewed version of this article. The final, definitive version of this document can be found online at Journal of Radio \& Audio Media, published by Taylor and Francis. Copyright restrictions may apply. doi: 10.1080/19376529.2014.891210

communicate and assigned the job of enforcing the new law to the Bureau of Navigation within the Department of Commerce and Labor. The Act did not deal with the problem of interference. In fact, interference may have actually increased in the wake of the new mandate.

Problems of interference and chaotic usage of frequencies were not unique to the U.S., and this confusion became apparent around the world with the sinking of the Titanic on April 15, 1912. Nearby ships were unable to receive the Titanic's distress signal because wireless operators were not on duty, and rescue efforts were hampered by interference caused by amateur operators (Barnouw, 1966; Douglas, 1987). Shortly thereafter, another International Radiotelegraph Convention was held, this time in London, and 45 nations were represented. In addition to establishing new standards for wireless communication, the London convention agreed that all radio transmitters and their operators had to be licensed (United States Navy Department, 1912). A unanimous resolution suggested that individual governments should institute these requirements; it was not a controversial idea in the wake of the Titanic disaster (Howeth, 1963, p. 165). The U.S. passed the Radio Act of 1912, which reflected the new international agreements. This legislation required radio stations to be licensed, a duty which was placed in the hands of the Department of Commerce. Little attention was paid, however, to how Commerce officials were to go about doing this (Kahn, 1984; Rowland, 1997). No potential grounds for denying licenses were given, and chaos was virtually guaranteed. But in 1912, this oversight hardly mattered, as demand for licenses remained low until the radio explosion in the early 1920 s.

The only specific mention of the "public" in the 1912 Act and the regulations put in place by the Department of Commerce and Labor was in the context of classification of "land stations," which separated "general public service stations" from "limited commercial" stations. General public service stations were those "required to maintain a constant receiving service" by the Interstate Commerce Act of 1887. This provision effectively brought to life the requirements of the 1906 Berlin convention that coastal stations should be available to send and receive all signals. "Limited commercial stations" received special licenses to transmit commercial messages on certain wavelengths and were not open to "public" service (Department of Commerce and Labor, 1912).

Thus, the effect of the Radio Act of 1912 was to favor "the navy by awarding it a dominant position in the electromagnetic spectrum and by specifically protecting its stations from interference by private companies" (Rosen, 1980, p. 21). The Act also effectively relegated amateur operators to high, largely unusable frequencies. General Electric and American Telephone and Telegraph, working with the Navy, continued to experiment and grow, developing new technologies that would soon outpace the Marconi Company. AT\&T was the first company to send wireless voice signals across the Atlantic in 1915. Thus, a number of shifts were taking place in the years between the 1912 Radio Act and the end of the decade. As the Navy and corporations gained greater control, the technology was being transferred "from individual to institutional control," and there was a tendency in the press "to legitimate corporate visions of how radio should be managed, thought about, and used” (Douglas, 1987, p. 240).

During this period, the Navy's dominance over wireless also grew as many officials, principally Secretary of the Navy Josephus Daniels, continued to advocate for the rest of the decade for a full government monopoly in the hands of the Navy. The First World War intensified this advocacy and made it easier to justify. In 1914, as fighting broke out in Europe, President Wilson issued a proclamation "to prohibit U.S. wireless stations from engaging in nonneutral conduct” (Rosen, 1980, p. 23). Daniels wanted more. As he told The Wireless Age in February 1917: "Authority to take over and operate or to close commercial stations in time of war will not suffice. The stations must be in full Government operation before the first hint of possible hostilities." Daniels went on to complain about interference and confusion resulting from too many competing interests. "I am firmly convinced that Government control of wireless is absolutely necessary to the best interests of the nation. I deem the matter most urgent. Delay only will increase the difficulties under which we are working; delay also will mean an increased outlay to the Government when the step finally is decided upon” (“Government Ownership of Wireless,” 1917, p. 301). By 1917, when the U.S. entered the war, the president authorized a Navy takeover of all wireless communication devices. The Navy responded by purchasing all but 15 of the privately owned wireless stations in the U.S., most of them owned by the Marconi Company and Lee De Forest (Rosen, 1980).

At this point, the Navy had some support in Congress and among newspaper publishers, who after the war, had become eager to use the navy's wireless stations to receive news from abroad, especially from across the Pacific. California Representative Charles F. Curry introduced House bill 8783, "authorizing the use of radio stations under 
the control of the Navy Department for commercial and other purposes.” In hearings before the Subcommittee on the Merchant Marine and Fisheries, Curry made it clear that he was not advocating a government takeover, but rather government supervision and facilitation of commercial operations.

Personally I am not in favor of public ownership or Federal ownership of railroads or telegraphs, telephones, or radio, or other public utilities. I used to think that probably the Federal Government could give good service in those lines, but the railroad control has disabused my mind entirely of that idea up to the present.

This bill of mine is not a Government-ownership bill. It simply authorizes and directs the Secretary of the Navy to use the radio station where it can be done without detriment to the public business, for the transmission of commercial and news radio and radiograms from overseas, and it fixes a minimum rate of charge.

My interest in the bill, and Mr. McClatchy's interest in the bill, is simply in the interest of giving right news to the American people, through American sources... ("Authorizing Use of Radio Stations," 1919, p. 3-4).

Newspaper publisher V.S. McClatchy also spoke to the committee, noting that "between Government control of radio facilities and private control I have no suggestion to offer," but he did call for government to supply the "necessary radio facilities" and a "very low-word rate” across the Pacific. McClatchy continued:

In my judgment, that is the proper and most effective policy to secure an independent report. There will be no embarrassment to the Government, as there has been in the past, no charge that the news which it is furnishing is propaganda or partisan, but it will insure the confidence on the part of the public which comes from such an independent report ("Authorizing Use of Radio Stations,” 1919, p. 4-5).

This bill and testimony introduced the idea that the government could and should facilitate the reporting of news as a public service even without a full takeover of industry.

An opposing view came from Edward J. Nally, Vice President and General Manager of Marconi Wireless Telegraph Co., of America, who testified before a Senate Subcommittee of the Committee of Naval Affairs regarding the same House bill and a similar Senate bill. Nally's view was that "the Navy should not go into commercial business," though he stated that private companies would be willing to use existing naval stations, saying he would not want "to prevent the operation of those facilities in the public interest." What this statement meant was the company wanted to avoid building duplicate stations if it could receive the same benefit using the Navy's. Nally recommended that the Navy operate commercially within the U.S. but should not engage in overseas operations. He noted: "But so far as international service is concerned, I feel that that is purely the function and field of a private company. I think private companies can best serve the public interests" ("Use of Naval Radio Stations for Commercial Purposes,” 1919, p. 205). Once again, business interests were helping to define the public interest as their own.

In this context, the major American communications firms emerged and took control of wireless. Marconi had been hailed as "hero-inventor" by the American press, and his company had helped make the case for commercial interests in Congress, but after the war, many American officials did not like the idea of a vital national and economic resource in the control of Marconi, a foreign company, and wanted to avoid giving control back after the war (Starr, 2004). At this fateful moment, General Electric set up the Radio Corporation of America as a subsidiary in 1919 and offered a takeover deal to the Marconi Company, which was forced to accept (Barnouw, 1966; Burns, 1977). RCA had the backing of a government-sanctioned monopoly, leading to a period of collusion between RCA, GE, AT\&T and eventually Westinghouse in order to make use of each other's patents and delineate manufacturing responsibilities and shares of the market for different types of wireless equipment (Douglas, 1987). This critical shift of control back to corporate hands would facilitate continued innovation and enterprise, and would also help position the newly emerging commercial interests to gain control over radio in the 1920s. The revolution in radio in the early 1920s would bring massive new excitement about the technology, but the story of institutional control would not change; that foundation had already been laid. 


\section{Britain: The First Wireless Act}

The story of wireless technology in Britain at the turn of the century is somewhat less complicated thanks to an early decision that would avoid the battle for control among government departments that defined the early 1900s in America. Britain emerged from the nineteenth century with a powerful telegraph network, both wired and wireless. By 1899, the first British ships were outfitted with wireless equipment, and Britain also dominated the industry for undersea cables. "In 1896, there were thirty cable laying ships in the world and twenty-four of them were owned by British companies. In 1892, British companies owned and operated two-thirds of the world's cables and by 1923 their share was still 42.7 percent” (Headrick \& Griset, 2001, p. 543). As the telegraph and related industries grew, the British Post Office sought to extend its control from wired telegraphy, as established by the 1869 Telegraph Act, to wireless. The 1904 Wireless Telegraphy Act did just this. Although the Act would have to be renewed several times, this authority would not be challenged in Britain as it was in the U.S. (Briggs, 1961).

The British Post Office went about taking control of Marconi's patents, for which the company was compensated, and issuing licenses to existing transmitters and receivers of wireless messages and to experimenters seeking to further develop the new technology. In 1909, Postmaster General Sydney Buxton, who had assumed that the Post Office's purview over wired transmissions extended naturally to wireless, expressed his satisfaction with this arrangement:

I am satisfied that it is to the public interest, both from a commercial and a strategical point of view, that the coast stations used for communication with ships should be in the hands of the Government, and should be worked as part and parcel of the general telegraphic system of the country. I think it important also that no private monopoly in wireless telegraphy should be allowed to glow up. I trust that the new arrangements will result in an even more rapid extension of the use of this important invention than has taken place in the past (Hansard, 30 September 1909, col 1409).

Even though competition existed under this scheme, there was a perception of a monopoly held by Marconi's company, and this control was thought to violate public interest. This suspicion was especially true as the Postmaster General began, in 1912, to call for a chain of Imperial Wireless Stations to be built in cooperation with Marconi. Sir Henry Norman submitted that the proposed arrangements between the Post Office and the Marconi Company had been criticized on two grounds: "first, that it is a bad bargain, an imprudent bargain; and, second, that it is a bargain which is tainted with corruption" (Hansard, 11 October 1912a, col 667). Sir Norman added: "I submit, therefore, that to stereotype-to petrify-Imperial wireless on the Marconi system without giving all these competitive systems even a hearing, would be wholly opposed to the public interest..." (Hansard, 11 October 1912b, col 682). Debate in Parliament would go on until the release of the Imperial Wireless Report in 1920. It is clear, however, that monopoly practices were viewed by some as antithetical to the public interest, which favored competition among parties engaged in free enterprise.

The dilemma, however, became moot when, in 1914, at the start of the First World War, the British government took control of all broadcasting, clearing the airwaves of amateurs and experimenters (Briggs, 1961). In one area Britain led the U.S., because America did not enter the war until three years later. Although this late entry gave the U.S. extra time to continue with experimentation, wireless progress did not cease in Britain. Engineers continued to develop the valves used in wireless transmissions, and British soldiers, sailors and airmen were introduced to the new technology during the war only to become experimenters themselves when the war was over.

In addition to these developments, the First World War helped to legitimize the concept of public service utilities in Britain. The government took on new roles that were initially only justified by the war, but these roles would outlast the war. This social shift was instrumental in the eventual formation of the BBC, as Curran and Seaton suggest:

Despite bitter opposition the centralized control of health, insurance, coal, and ultimately the rationing of food had been introduced. These were seen as exceptional war-time measures. By the 1920s, however, a generation of reformers who had been civil servants during the war were experienced in organizing the centralized distribution of resources. Indeed for a brief period after the War even the government accepted a more interventionist role. The BBC was formed in this period (Curran \& Seaton, 1997, p. 139). 
This is an author-produced, peer-reviewed version of this article. The final, definitive version of this document can be found online at

Journal of Radio \& Audio Media, published by Taylor and Francis. Copyright restrictions may apply. doi: 10.1080/19376529.2014.891210

This account shows how the impact of the war on communications differed in the U.S. and Britain. The more limited nature of the role the U.S. played in the war may have influenced the different attitudes toward state intervention in public services. After the war, the U.S. was eager to get back to the business of private enterprise, unencumbered by the state.

By the war's end, new technology was bringing the possibility of broadcasting ever closer. "With the end of the Great War in 1918 it became harder for the British government to resist on military grounds the pressure from both wireless manufacturers and amateur enthusiasts to authorize some kind of regular broadcasting service" (Crissel, 2002, p. 17). Radio enthusiasts wanted something to listen to, and "manufacturers were keen to stimulate the sales of receiving equipment and were willing if need be to provide the service themselves" (p. 17). The Post Office licensed the Marconi Company to make limited broadcasts from its transmitter at Writtle near Chelmsford, beginning in 1920.

Meanwhile, the British government was still focused on how to structure and regulate the new technology based on its use in point-to-point communication applications. A system of Imperial Wireless Communication, possibly to be built by the Marconi Company, had been suggested for years prior to the convening of the Norman Commission, or the Imperial Wireless Telegraph Committee, which released its report on May 28, 1920 (Report of the Imperial Wireless Telegraphy Committee, 1920). The committee was charged with preparing "a complete scheme of Imperial wireless communications in light of modern wireless science and Imperial needs” (p. 1). This included considering "what high-power stations it is desirable on commercial or strategic grounds that the Empire should ultimately possess" (p. 1). They were also to examine capital requirements and costs, traffic and revenue, and make recommendations. The committee predicted that naval bases, military headquarters and aviation centers would also serve as commercial centers and that the needs of all of these would be met by the same station.

The committee laid out the factors it thought necessary for a satisfactory commercial wireless service: reliability, speed and cheapness. "If the service aims at becoming self-supporting, while offering low rates to the public, sufficient paying traffic must ultimately be secured to keep the stations occupied for practically twenty-four hours a day at high speed” (Report of the Imperial Wireless Telegraphy Committee, 1920, p. 4). The committee felt that this was not likely to be achieved in the hands of commercial services.

Of the financial results of existing long-range wireless services we have no knowledge, but as regards only speed and accuracy, including the avoidance of excessive repetition, we are of opinion that no satisfactory commercial wireless service, as we have defined the expression, is in operation anywhere to-day over a distance of 2,000 miles (Report of the Imperial Wireless Telegraphy Committee, 1920, p. 4).

The committee report discusses different types of transmitting technology and construction of stations throughout the empire in such places as New Zealand, Singapore, India and South Africa. More importantly, the committee was asked to consider a proposal by Marconi's Wireless Telegraph Company to build the imperial network. The committee noted that the Marconi Company's scheme "is of a scope and magnitude never hitherto contemplated" (p. 16) and expressed their discontent with the proposed confluence of private and state power.

The report goes on to suggest that the proposal by Marconi would preclude wireless development by other entities and would discourage competition and research. It would curtail the possibility of employment for wireless technicians or operators and "would tend to deprive the services and the Post Office of their best engineering personnel" (p. 17). This concern for jobs and for a sort of "brain drain" away from the departments of state expresses a sentiment unlike anything seen in the U.S. The committee ultimately regards "the inclusion of virtually all civilian wireless activity in the hands of one commercial company as likely to be deeply prejudicial to research and progress" (p. 17). The report goes on to consider that the Marconi proposal would amount to a complete private monopoly of the airwaves in Britain and beyond. Rejecting this, but recognizing that the limited airwaves required a monopoly of some sort, the committee expounded on the virtues of public ownership and control by the state mixed with an oligopoly of regulated but privately owned stations: 
We are of opinion that, in order to secure efficient working, an Imperial system, by whomsoever provided, must be protected from interference from other sources, and must, therefore, be a practical monopoly. But a State monopoly of this kind would not preclude private enterprise in other spheres of wireless activity.... On the other hand, the grant of a practical monopoly such as that asked for by the Marconi Company excludes the State altogether (p. 17).

Ultimately, the commission did recommend the establishment of an Imperial wireless telegraph network, and proposed that it be entrusted to the Engineering Department of the General Post Office. It even acknowledged that the system would operate initially at a loss, but that loss would be worth the ultimate benefit to the empire (p. 28).

This Imperial Wireless Telegraph Committee, also referred to as the Norman Commission, does not often appear in histories of British broadcasting. It is tangential to broadcasting itself, and it had no immediate impact on policy. The concerned parties continued to debate for another two years before an outcome was achieved. This result came in 1922 in the form of the British Broadcasting Company - a publicly controlled oligopoly of six privately owned radio manufacturers-just as the Norman Commission proposed. The outcome, however, was not a foregone conclusion, at least not until British officials considered what was happening in the U.S.

\section{Conclusion}

This case comparison of early broadcast policy and debate in the U.S. and Britain suggests that even before the crucial government acts of the 1920s, causal chains had formed. The comparative historical institutional analysis employed here helps illustrate the influence of competing social, political and economic forces in shaping divergent policy outcomes, and it helps to highlight the ways in which today's powerful actors might be competing for control of a range of modern digital communication technologies.

Prior to the radio boom in the 1920s, both the U.S. and Britain had spent considerable time and energy debating the merits of the different approaches to the structure of wireless communications, and the systems up to this point still represented a chaotic mix of public and private ownership and control. Early international agreements emphasized public service, but emerging policies diverged. British officials remained wary of monopolized private power in the hands of Marconi, but the U.S. expressed an early preference for a light regulatory touch by the commerce department. Policies in both nations became jumbled largely due to the influence of the First World War, which mandated a complete government takeover of wireless in both countries. The post-war period was one of great contingency. With wireless firmly in the hands of government, both nations had to decide whether to make this approach permanent through peacetime legislation or to somehow turn wireless communications back over to industry and enthusiasts. Britain favored the former approach while America preferred the latter.

Nevertheless, in the long causes of the path-dependent processes leading to the eventual outcomes for broadcasting, inertia continued to grow in each country, and cumulative and incremental changes were building toward the breaking point that would be reached in the coming years. In Britain, the early government control of wireless would make it easier to retain government control of broadcasting as a policy option. In the U.S., policy options were gradually being removed as Congress came to favor private business over government control. In these contexts, policy scripts were being written, and the public interest was being defined in increasingly divergent ways. In the U.S., a theoretically negative conception of liberty informed the "wait-and-see" approach by a government that was hesitant to interfere with private business outside of wartime. In Britain, a more positive view of liberty was evident in government efforts to promote wireless as a public service and regulate the ambitions of private business. The idea of broadcasting was just beginning to take shape, and all of the preexisting conceptions of the state's role in regulating communications were about to be challenged, but the paths that had led to this point would have consequences. Today, the resonance of these consequences continues to be felt as policymakers, experts and citizens debate the proper role of the state when it comes to such topics as network neutrality, broadband access, and the digital divide. Indeed, history is not a series of events but rather a process that leads to certain events, and the paths of history continue to exert their influence as the process continues. 


\section{References}

Arthur, B. W. (1989). Competing technologies, increasing returns, and lock-in by historical events. The Economic Journal, 99(394), 116-31.

“Authorizing Use of Radio Stations Under Control of Navy Department for Commercial Purposes,” Hearings before the Subcommittee on the Merchant Marine and Fisheries, House of Representatives, 1st session, 66th Congress, Part 1. (September 26, 1919). Washington, D.C.: Government Printing Office.

Barnouw, E. (1966). A tower in babel: A history of broadcasting in the United States to 1933, Vol. 1. New York: Oxford University Press.

Baumgartner, F. R., \& Jones, B. D. (2009). Agendas and instability in American politics (2nd ed.). Chicago: The University of Chicago Press.

Briggs, A. (1961). The history of broadcasting in the United Kingdom part I. London: Oxford University Press.

Burns, T. (1977). The BBC: Public Institution and Private World. London: Macmillan.

Crisell, A. (2002). An introductory history of British broadcasting (2nd ed.). London: Routledge.

Curran, J., \& Seaton, J. (1997). Power without responsibility: The press and broadcasting in Britain (5th ed.). London: Routledge.

Department of Commerce and Labor, Bureau of Navigation. (September 28, 1912). Regulations Governing Radio Communication. Washington, D.C.: Government Printing Office.

Douglas, S. J. (1987). Inventing American broadcasting, 1899-1922. Baltimore: Johns Hopkins University Press.

“Government Ownership of Wireless,” The Wireless Age, February 1917, 301.

Hansard HC Deb (30 September 1909) vol 11 cc1408-10.

Hansard HC Deb (11 October 1912a) vol 42 cc667-750.

Hansard HC Deb (11 October 1912b) vol 42 cc667-750.

Headrick, D. R., \& Griset, P. (2001). Submarine telegraph cables: Business and politics, 1838-1939. The Business History Review 75(3), 543-578.

Howeth, L. S. (1963). History of Communications-Electronics in the United States Navy. Washington, D.C.: Government Printing Office.

Inter-Departmental Board Appointed by the President to Consider the Entire Question of Wireless Telegraphy in the Service of the National Government. (1905). Washington, D.C.: Government Printing Office. Reproduced in Howeth, History of Communications-Electronics, Appendix C.

International Radio Telegraph Convention. (July 5, 1912). London: HM Stationery Office.

International Wireless Telegraph and Hearings, First Session, Sixtieth Congress. Washington, D.C.: Government Printing Office, 1908.

John, R. R. (2010). Network nation: Inventing American telecommunications. Cambridge, Mass.: Belknap Press.

Kahn, F. J. (ed.). (1984). Documents of American broadcasting. Englewood Cliffs, N.J.: Prentice-Hall.

"Letter from the Inter-Departmental Board on Wireless Telegraphy to the Department of Commerce and Labor." (29 July 1904). Washington, D. C., July 29, 1904.

Pierson, P. (2000). Increasing returns, path dependence, and the study of politics. The American Political Science Review 94(2), 251-67.

Pierson, P. (2004). Politics in time. Princeton: Princeton University Press.

Pierson, P., \& Skocpol, T. (2002). Historical institutionalism in contemporary political science. In I. Katznelson \& H. V. Milner (Eds.), Political science, state of the discipline (693-721). New York: W.W. Norton. Report of the Imperial Wireless Telegraphy Committee (1919-1920). Cmd. 777.

Rosen, P. T. (1980). The modern stentors: Radio broadcasters and the federal government, 1920-1934. Westport, Conn.: Greenwood Press.

Rowland, Jr., W. D. (1997). The meaning of “the public interest” in communications policy, part II: Its implementation in early broadcast law and regulation. Communication Law \& Policy 2(4): 363-396.

Sewell, Jr., W. H. (1996). Three temporalities: Toward an eventful sociology. In T. J. McDonald (Ed.), The historic turn in the human sciences (245-280). Ann Arbor: University of Michigan Press.

Slotten, H. R. (2000). Radio and television regulation: Broadcast technology in the United States, 1920-1960. Baltimore: Johns Hopkins University Press.

Starr, P. (2004). The creation of the media: Political origins of modern communications. New York: Basic Books.

Thelen, K. (1999). Historical institutionalism in comparative politics. Annual Review of Political Science, 2, 369404. 
Tower, C. (Letter dated Nov. 25, 1906). Ambassador C. Tower to the Secretary of State, files, Bureau of Equipment, National Archives, Washington, D.C. Reproduced in Howeth, History of Communications-Electronics, 120.

United States Navy Department. (1912). International Radio Telegraph Convention of Berlin: 1906. Washington, D.C.: Government Printing Office.

"Use of Naval Radio Stations for Commercial Purposes, Hearings Before a Subcommittee of the Committee on Naval Affairs,” US Senate, 1st session, 66th Congress. (1919). Washington D.C.: Government Printing Office. 